\title{
Sistem Informasi Manajemen Pemesanan Jasa Percetakan Berbasis Web
}

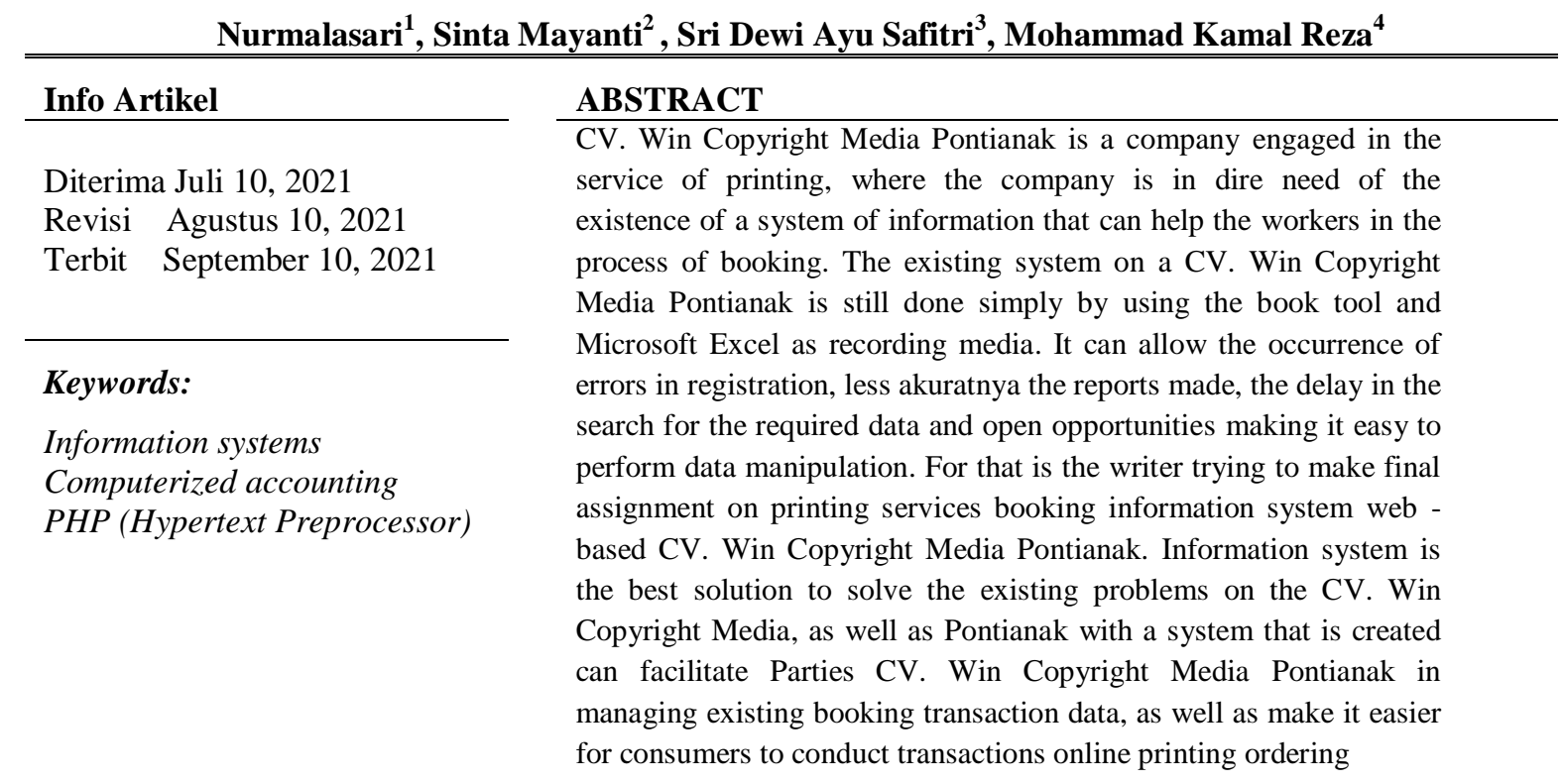

\author{
Identitas Penulis: \\ Nurmalasari ${ }^{1}$, Sinta Mayanti ${ }^{2}$, Sri Dewi Ayu Safitri ${ }^{3}$, Mohammad Kamal Reza ${ }^{4}$ \\ Universitas Bina Sarana Informatika \\ Email: nurmalasari.nrr@bsi.ac.id ${ }^{1}$, sinta.mayantii05@gmail.com², sri.sdf@bsi.ac.id ${ }^{3}$, \\ mohammad.mkz@bsi.ac.id
}

\section{PENDAHULUAN}

Semakin canggih teknologi maka semakin mempermudah pihak perusahaan dalam melakukan pekerjaan bahkan mendorong untuk mencari inovasi dalam mengembangkan perusahaan agar bisa dikenal semua kalangan masyarakat. Hal yang terpenting terutama dalam pemesanan produk, pihak perusahaan harus berinovasi dan memikirkan bagaimana pemesanan yang dilakukan akan mempermudah pihak pelanggan dalam memesan suatu produk dengan mudah dan cepat tanpa mengeluarkan modal yang besar, karena tidak harus datang kelokasi untuk memesan melainkan via online.

Manfaat dari suatu teknologi adalah untuk pemesanan produk. Dengan hal ini tentu dapat diterima oleh semua kalangan masyarakat. Mengingat kebanyakan dari masyarakat yang sudah terbiasa dengan menggunakan teknologi yang dapat mengakses internet dalam memenuhi kebutuhan sehari-hari. CV. Win Cipta Media membutuhkan sistem informasi yang dapat memudahkan pengguna dalam mengelola data pemesanan dan data customer dalam memesan produk secara online.

CV. Win Cipta Media merupakan salah satu perusahaan yang bergerak di bidang jasa percetakan digital (Digital Printing). Dalam kegiatan pemesanan jasa percetakan. CV. Win Cipta Media pencatatan transaksinya masih dilakukan dengan tulis tangan di buku transaksi sehingga dokumen-dokumen tersebut dapat terjadi hal-hal tidak diinginkan seperti dokumen basah, rusak, hilang karena tidak berupa bentuk digital.

Pencatatan pemesanan produk dilakukan dengan tulis tangan mengakibatkan pencatatan laporan memakan waktu yang lama. Data pemesanan produk tidak tertata dengan benar dan proses pemesanan yang dilakukan hanya melalui telepon, aplikasi WhatsApp (WA) dan Instagram sehingga data pemesanan tidak tertata dengan baik sehingga status pemesanan produk tidak bisa diketahui oleh karyawan baik yang baru order, ataupun yang telah selesai pesanannya.

Hal ini tentu menjadi penghambat bagi CV. Win Cipta Media dalam mengembangkan perusahaannya karena informasi dan proses pemesanan belum memiliki sistem informasi untuk mengolah data-data.

\section{METODE}


Metode Penelitian adalah cara atau strategi yang ditempuh untuk melakukan suatu penelitian. Dalam penyusunan penulis menggunakan metode penelitian deskriptif dengan beberapa emtode pengumpulan data seperti (1) observasi, pegamatan secara langsung ke perusahaan CV. Win Cipta Media untuk melihat proses kegiatannya seperti pengisian form oleh customer yang ingin memesan produk sampai proses pelaporan pemesanan produk serta mendapatkan informasi yang diinginkan untuk menganalisa proses pemesanan produk yang dilakukan. (2) Wawancara langsung kepada Bapak Wiwiwn,SE selaku pemilik perusahaan (3) Studi pustaka, mengambil referensi yang bersumber dari buku, artikel dan jurnal serta referensi lainnya.

\section{1 metode pengembangan software}

Penulis melakukan pengembangan sistem dengan metode SDLC (Sistem Development Life Cycle), dengan model Waterfall. SDLC (Software Development Life Cycle). SDLC atau Software Development Life Cycle adalah proses mengembangkan atau mengubah suatu sistem perangkat lunak dengan menggunakan model model dan metodologi yang digunakan orang untuk mengembangkan sistem-sistem perangkat lunak sebelumnya. Metode waterfall adalah "Air terjun (Waterfall) sering disebut juga model sekuensial linier (sequential linear) atau alur hidup klasik. [1]

\subsection{Web}

Web adalah suatu halaman yang memuat situs-situs web page yang berada di internet yang berfungsi suatu halaman yang memuat situs-situs web page yang berada di internet yang berfungsi sebagai media penyampaian informasi, berfungsi sebagai media penyampaian informasi, komunikasi, atau transaksi. [2]

Web sebuah bagian dari internet yang sangat dikenal dengan dunia internet, dengan adanya WWW maka klien dapat menampilkan sebuah virtual yang disebut dengan web site. [3]

\subsection{Sistem Informasi}

Sistem informasi merupakan gabungan dari empat bagian utama. Keempat bagian utama tersebut mencakup perangkat lunak (software), perangkat keras (hardware), infrastruktur, dan Sumber Daya Manusia (SDM) yang terlatih. Keempat bagian utama ini saling berkaitan untuk menciptakan sebuah sistem yang dapat mengelola data menjadi informasi yang bermanfaat. [4].Sistem Informasi merupakan sistem yang mempunyai kemampuan untuk mengumpulkan informasi dari semua sumber dan menggunakan berbagai media untuk menampilkan informasi.[5].

\subsection{Pengertian Pemesanan}

Pemesanan adalah suatu proses pembelian dimana barang yang akan dibeli harus dipesan terlebih dahulu sebelum sampai kekita.[6]. Dalam arti umum adalah perjanjian pemesanan tempat antara 2 (dua) pihak atau lebih, perjanjian pemesanan tempat tersebut dapat berupa perjanjian atas pemesanan suatu ruangan, kamar, tempat duduk dan lainnya, pada waktu tertentu dan disertai dengan produk jasanya.

\subsection{Entity Relationship Diagram (ERD)}

Entity Relationship Diagram (ERD) adalah suatu model jaringan yang menggunakan susunan data yang disimpan dalam secara abstrak. [7]. ERD merupakan suatu model untuk menjelaskan hubungan antar data dalam basis data berdasarkan objek-objek dasar data yang mempunyai hubungan antar relasi.[8].

\section{HASIL}

\subsection{Use Case Diagram}

Use case diagram merupakan diagram yang bekerja dengan cara mendeskripsikan tipikal interaksi antara admin sebuah sistem dengan suatu sistem tersendiri melalui sebuah cerita bagaimana sebuah sistem tersebut digunakan. Dibawah ini merupakan gambar use case diagram sistem pemesanan produk jasa percetakan sebagai berikut:

1. Use Case Admin

Use case ini memungkinkan admin untuk mengelola data barang,data kategori, data customer, data user, data pemesanan dan data pembayaran.

Berikut use case diagram halaman Admin: 


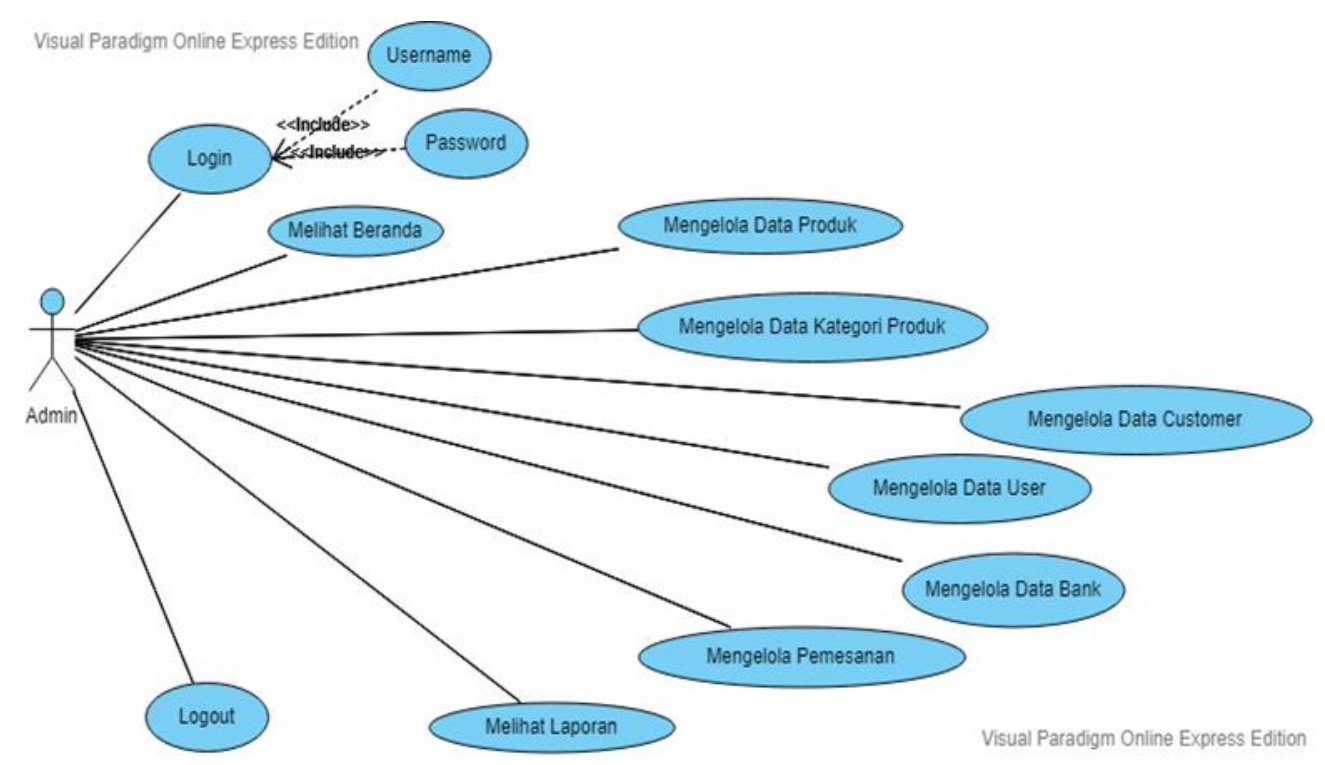

Sumber : Hasil Rancangan (2019)

Gambar 1 Use Case Diagram Halaman Admin

2. Use Case Kasir

Use case ini merupakan sistem yang memungkinkan kasir untuk mengakses beranda dan mencetak laporan. Berikut gambar use case diagram kasir. Berikut use case diagram halaman kasir:

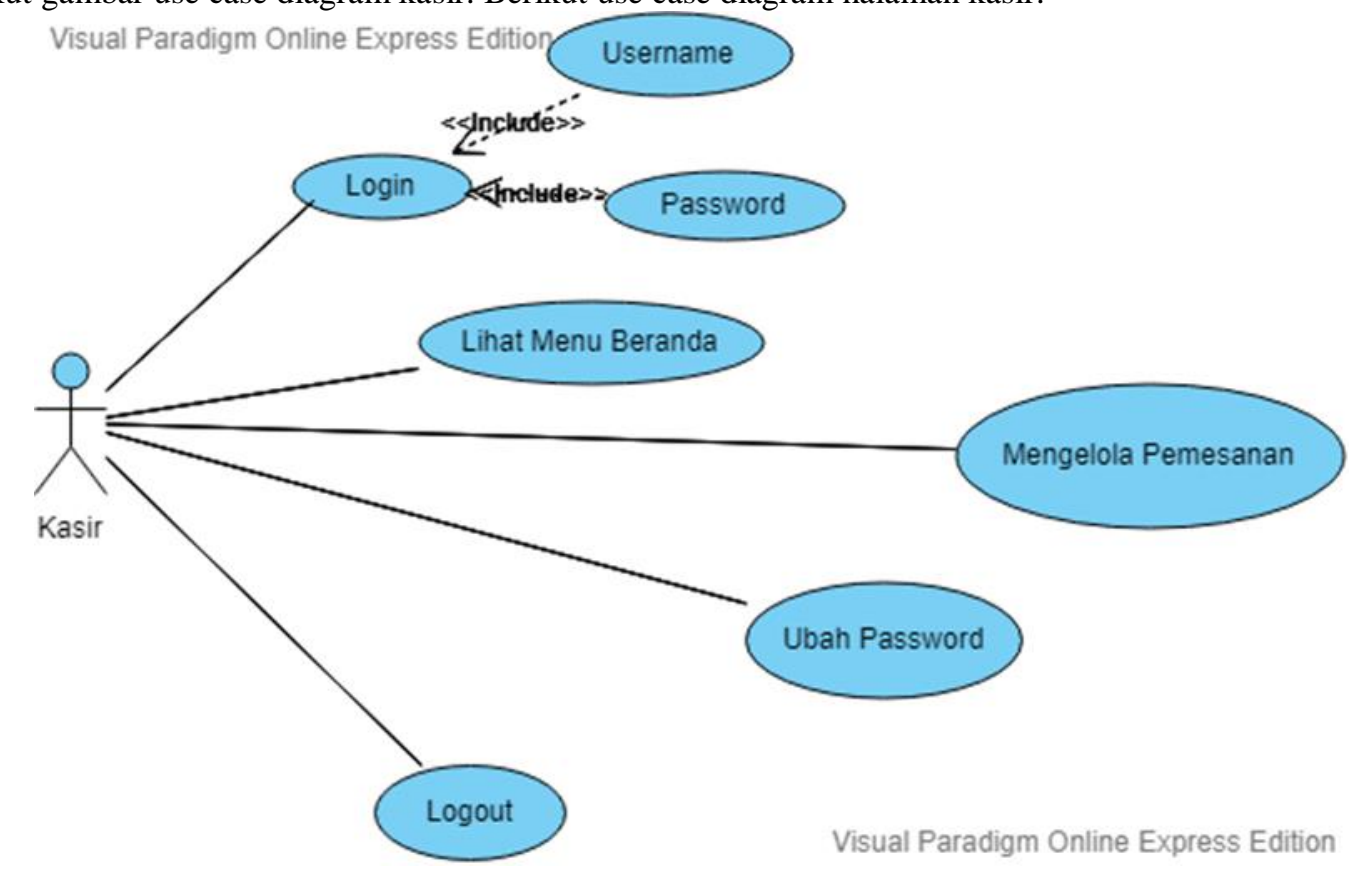

Sumber : Hasil Rancangan (2019)

Gambar 2 Use Case Diagram Halaman Kasir

\section{Use Case Customer}

Use case ini memungkinkan konsumen untuk login, masuk menu kategori dan melihat produk berdasarkan kategori, mengisi data-data pesanan, mencetak pesanan, melakukan registrasi pembayaran dan aploud bukti pembayaran. Berikut ini gambar use case diagram customer: 
Vol. 02, No. 02, September 2021, pp. 60 67

ISSN: 2721-7523

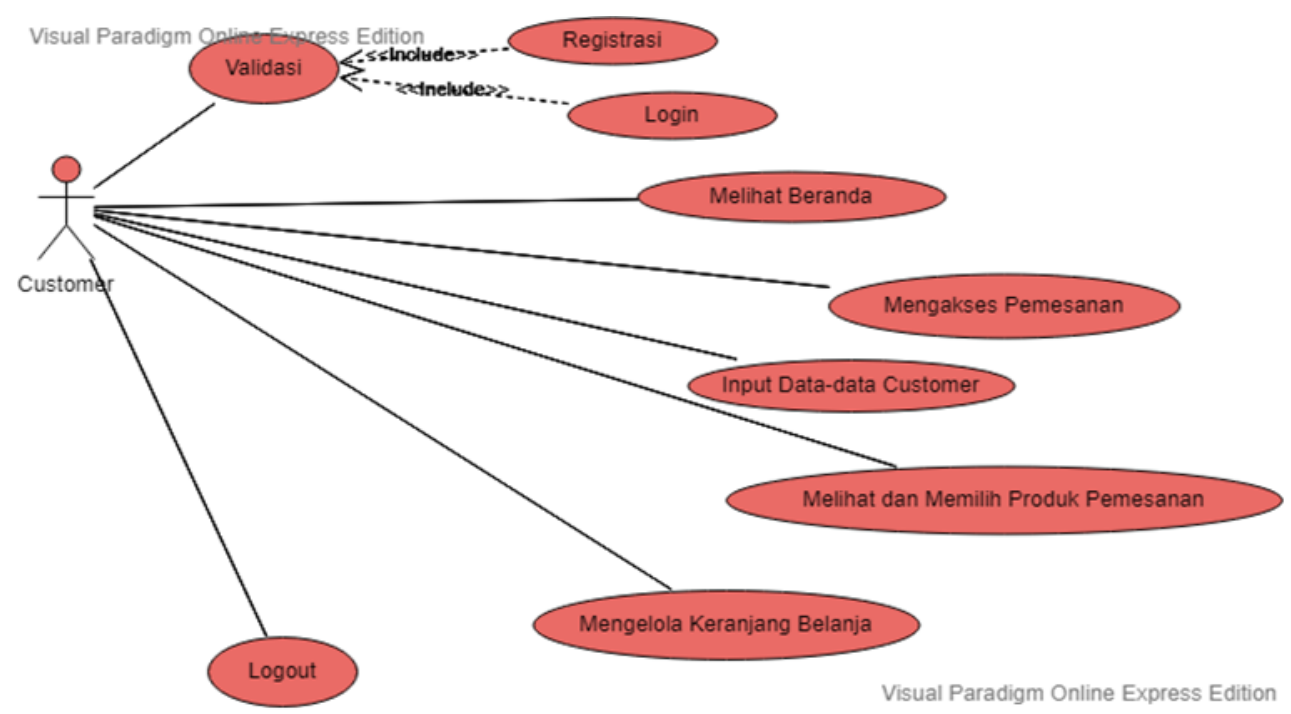

Sumber : Hasil Rancangan (2019)

Gambar 3 Use Case Diagram Halaman Customer

\subsection{Activity Diagram}

Activity Diagram akan menjelaskan aktifitas objek. Adapun activity diagram sistem informasi pemesanan jasa percetakan sebagai berikut:

1. Activity Diagram Menu Utama

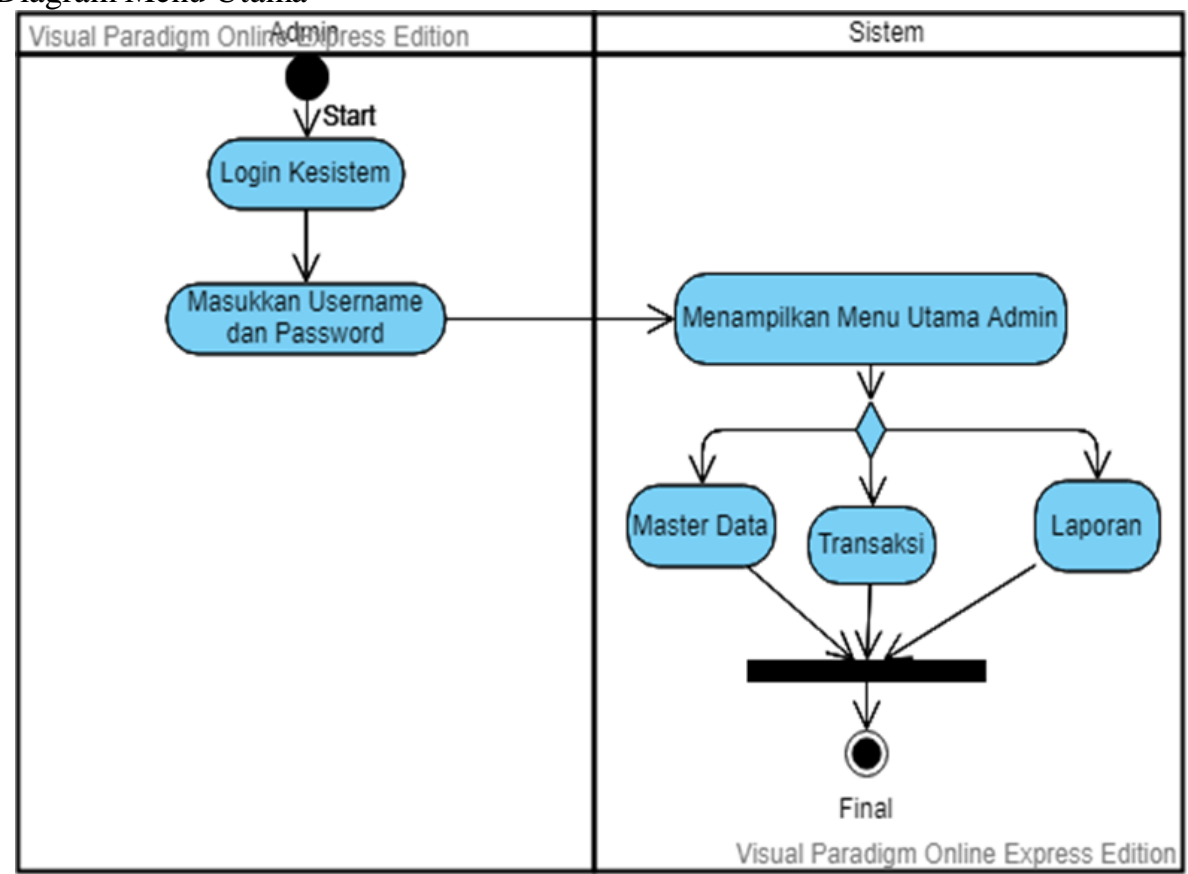

Sumber : Hasil Rancangan (2019)

Gambar 4 Activity Diagram Menu Utama

Gambar dibawah ini menjelaskan bagaimana aktivitas admin ke menu utama yang dapat mengelola menu master, transaksi dan laporan. 
Vol. 02, No. 02, September 2021, pp. 60 67

ISSN: 2721-7523

2. Activity Diagram Data Produk

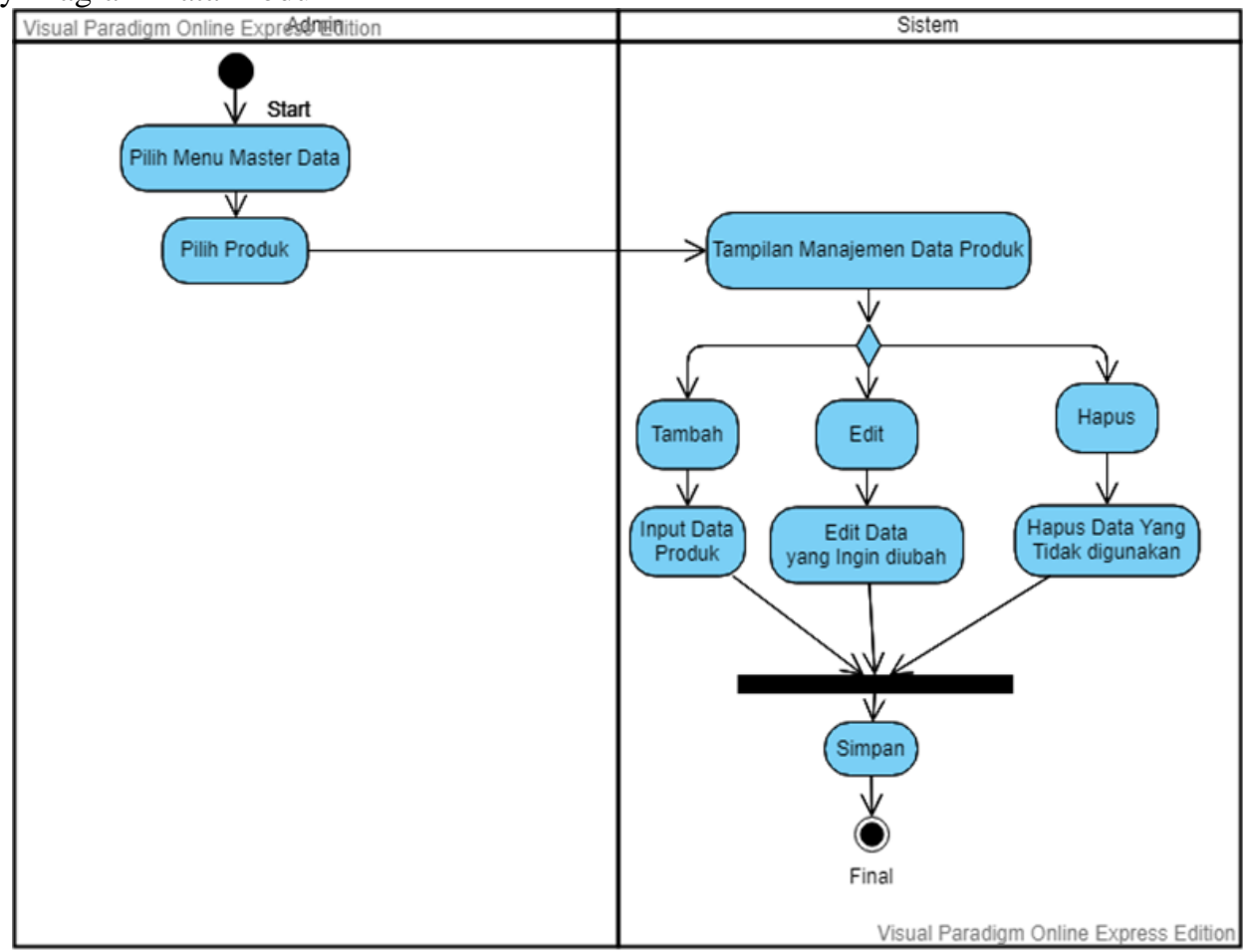

Sumber : Hasil Rancangan (2019)

Gambar 5 Activity Diagram Data Produk

Gambar dibawah ini menjelaskan bagaimana aktivitas admin ke data produk yang bisa menambah, mengedit, menghapus, dan menyimpan data yang akan diinput.

3. Activity Diagram Data Kategori Produk

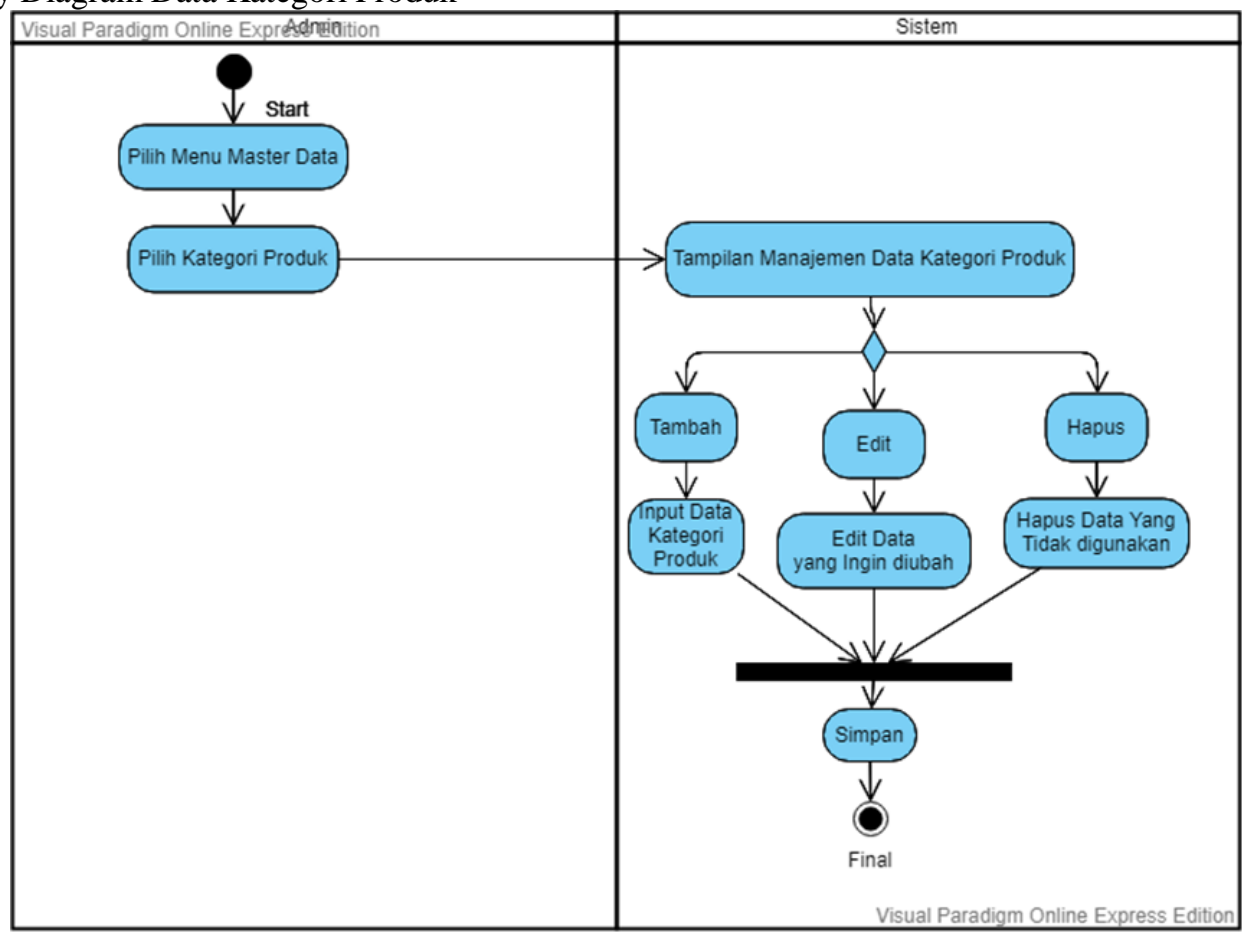

Sumber : Hasil Rancangan (2019)

Gambar 6 Activity Diagram Data Kategori Produk 
Gambar dibawah ini menjelaskan bagaimana aktivitas admin ke data kategori produk yang bisa menambah, mengedit, menghapus, dan menyimpan data yang akan diinput

3.3.User Interface

User interface merupakan tampilan tatap muka dengan user. Adapun user interface dalam Sistem Informasi Pemesanan Jasa Percetakan Berbasis Web Pada CV. Win Cipta Media sebagai berikut:

1. Halaman Customer

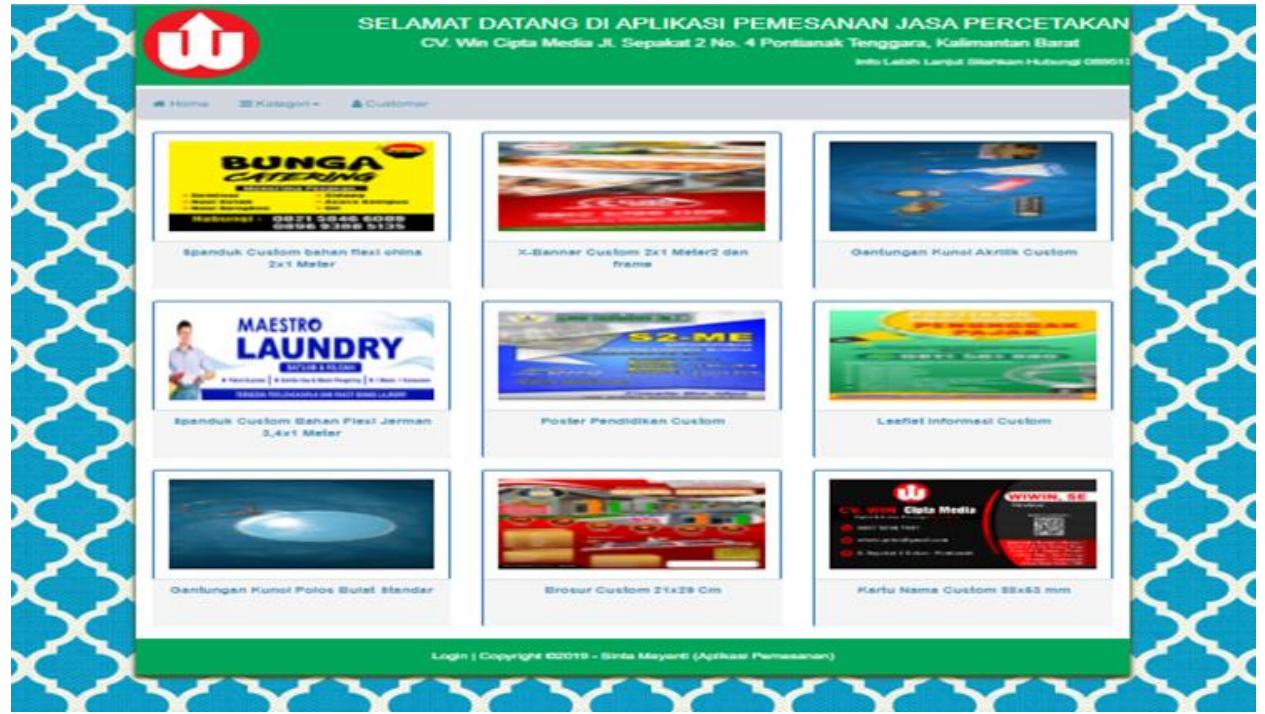

Sumber : Hasil Rancangan (2019)

Gambar 7. User Interface Halaman Utama Customer

Halaman utama ini memungkinkan customer untuk melihat produk, registrasi, login dan memesan produk.

2. Halaman Registrasi dan Login Customer

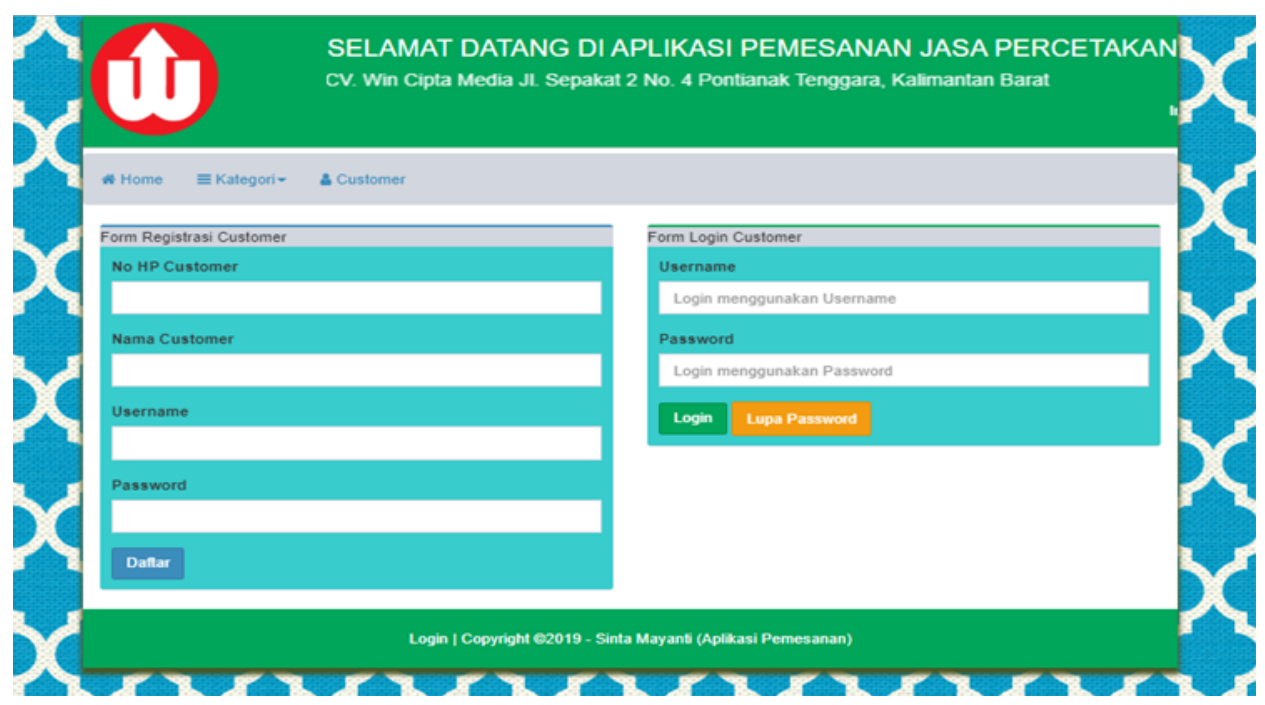

Sumber : Hasil Rancangan (2019)

Gambar 8. User Interface Registrasi dan Login Customer

Halaman ini customer akan mendaftarkan diri terlebih dahulu sebelum login, dan akan masuk ke halaman pemesanan produk. 
3. Halaman Input Jumlah Pemesanan Customer:

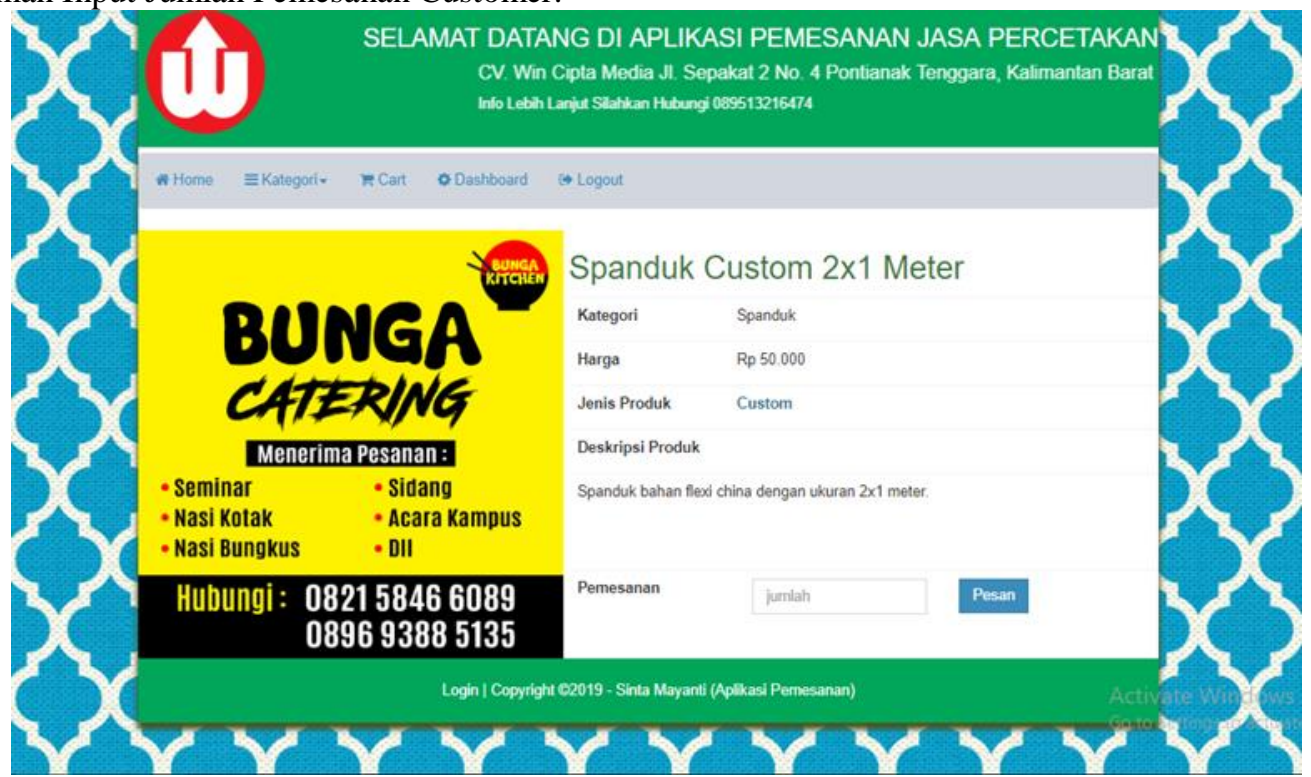

Sumber : Hasil Rancangan (2019)

Gambar 9 User Interface Input Jumlah Pemesanan Customer

Customer menginputkan jumlah pemesanan dan mengklik tombol pesan, sebagai tanda bahwa customer ingin memesanan produk yang telah dipilih.

4. Halaman Keranjang Belanja Customer

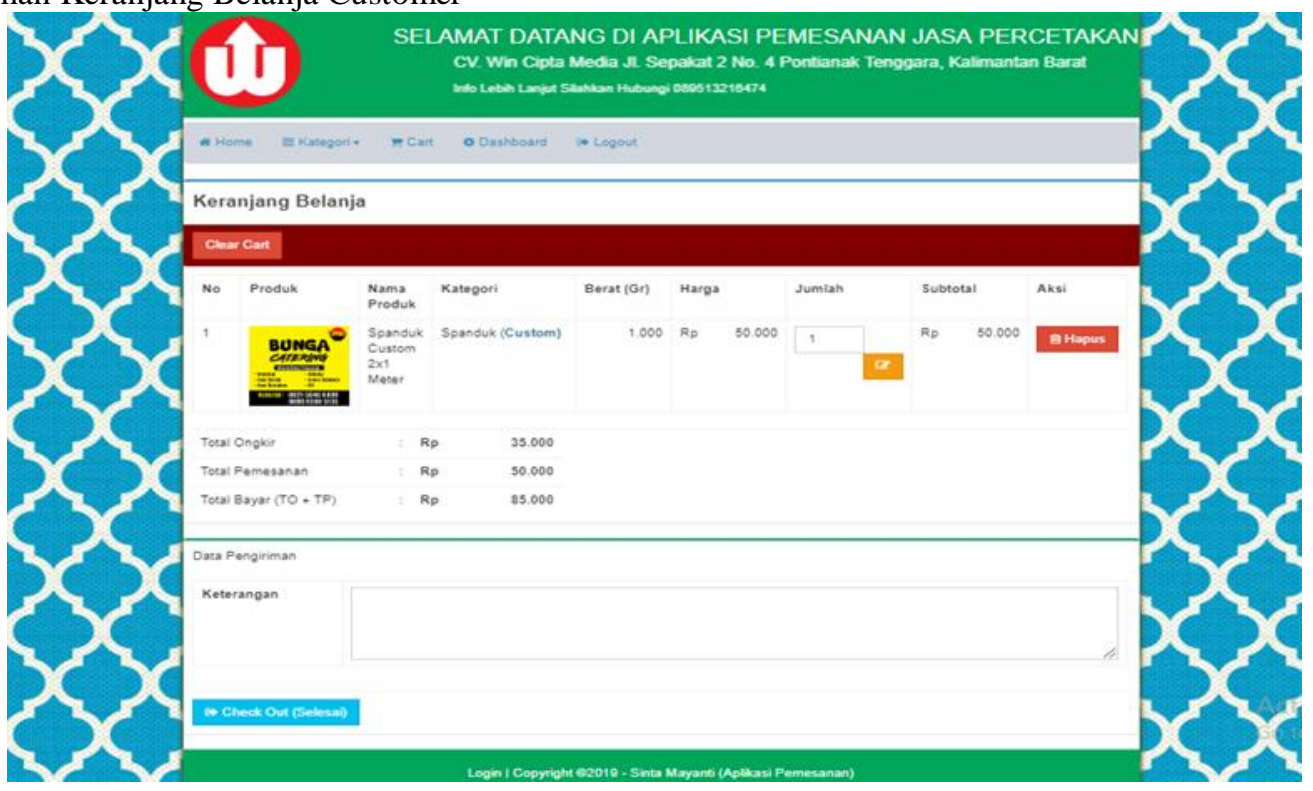

Sumber : Hasil Rancangan (2019)

Gambar 10 User Interface Keranjang Belanja Customer

Customer mengelola pemesanan yang telah dipesan, memungkinkan customer mengupdate jumlah pesan yang ingin diubah sesuai keinginan dan ketika sudah selesai customer menuliskan keterangan apa yang ingin disampaikan kemudian check out.

\section{KESIMPULAN}

Berdasarkan hasil penelitian ini dapat disimpulkan bahwa sistem pemesanan produk pada CV. Win Cipta Media Pontianak saat ini masih menggunakan pencatatan menggunakan tulis tangan sehingga masih banyak ditemukan masalah yang mengakibatkan lambatnya proses pemesanan, sering terjadi hilangnya data, dan sulitnya pencarian dokumen-dokumen pemesanan pada CV. Cipta Media Pontianak. Sistem Informasi Pemesanan Jasa Percetakan Berbasis Web Pada CV. Win Cipta Media Pontianak dapat digunakan untuk 
pemesanan jasa percetakan baik transaksi secara online ataupun konsumen datang langsung ke CV. Win Cipta Media Pontianak.

\section{UCAPAN TERIMA KASIH}

Terima kasih kami ucapkan kepada seluruh pihak terkait atas terlaksananya penelitian ini, terutama kepada Allah SWT, pihak dari CV.Cipta Media Pontianak, para reviewer serta kepada pihak penerbit yang telah berkenan untuk menerbitkan paper ini.

\section{REFERENSI}

[1] Rosa A.S dan M. Shalahuddin. 2014. REKAYASA PERANGKAT LUNAK TERSTRUKTUR dan BERORIENTASI OBJEK. Bandung: Informatika

[2] Hastanti, R. puji, Purnama, bambang eka, \& Wardati, indah uly. (2015). Sistem Penjualan Berbasis Web (ECommerce) Pada Tata Distro Kabupaten Pacitan. Bianglala Informatika, 3(2), 1-9. https://doi.org/10.1007/s13226$\underline{018-0284-5}$

[3] Handoko, S. G., Purnama, B. E., \& Sukadi. (2016). Pembuatan Website Pada UPTP Pusat Kesehatan Masyarakat Desa Kalak. Jurnal Evolusi, 4(2), 405-413. https://doi.org/10.16418/i.issn.1000-3045.2016.04.004

[4] Risdiiansyah, D. (2017). Perancangan Sistem Informasi Bimbingan Konseling Berbasis Desktop pada SMA Kemala Bhayangkari 1 Kubu Raya Deni. Khatulistiwa Informatika, V(2), 86-91.

[5] Kusnanjaya, A. (2014). PERANCANGAN SISTEM INFORMASI DATA GURU MENGGUNAKAN Administration information system is a system used to process data and process data master administration activities involving between teachers, administration pembimas Catholics and other staffing attri. Paradigma, XVI(1), 1-9.

[6] Nuzulahka, R. (2018). SISTEM PELAYANAN DAN PEMESANAN ONLINE PADA TOKO BANGUNAN SUMARNO JAYA DEPOK. Jurnal String, 2(3), 274-281.

[7] Rahmayu, M. (2015). RANCANG BANGUN SISTEM INFORMASI NILAI UJIAN SISWA SMP NEGERI 3 BUMIAYU BERBASIS WEB. Khatulistiwa Informatika, 3(2), 159-168.

[8] Firman, A., Wowor, H., \& Najoan, X. (2016). Sistem Informasi Perpustakaan Berbasis Web Application. Teknik Elektro Dan Komputer, 5(2), 29-35. https://doi.org/10.21456/vol1iss2pp69-72 